\title{
Iron Overload and HFE Mutations: Are They Relevant in Cryptogenic Cirrhosis?
}

\author{
Agustin Castiella ${ }^{1^{*}}$ \\ ${ }^{1}$ Gastroenterology Service, Mendaro Hospital, Mendaro, Spain
}

\begin{tabular}{l}
\hline A R T I C L E I N F O \\
\hline Article type: \\
Letter to Editor \\
\hline Article history: \\
Received: 29 Dec 2011 \\
Revised: 01 Jan 2012 \\
Accepted: 15 Jan 2012 \\
Keywords: \\
Iron Overlood \\
Genetic Diseases \\
Genes \\
\hline
\end{tabular}

\section{Dear Editor,}

Hereditary hemochromatosis $(\mathrm{HH})$ is the most frequent genetic disease in populations of European origin. The HH gene was cloned by Feder et al. in 1996, and 2 major mutations were discovered: C282Y and H63D. Geographical differences with mutation frequencies have been published $(1,2)$ with a decreasing gradient of occurrence in Europe from north to south. HH leads to liver iron overload and raised liver iron concentration (LIC) is associated with liver fibrosis. When the LIC reaches $60 \mu \mathrm{mol} / \mathrm{g}$, or approximately twice the upper limit of the normal range $(36 \mu \mathrm{mol} / \mathrm{g})$, activation of stellate cells appears. These cells are principally responsible for the beginning of liver fibrosis and fibrosis (3). This process can lead to hepatic cirrhosis at the end stage. So it is of interest to ask ourselves, for those patients with cirrhosis but without any known culprit as the cause, whether iron surcharge and mutations of the HFE gene that may induce this iron overload could play a relevant role in the etiopathogenesis of cryptogenic cirrhosis.

Jowkar et al. (4) have recently published a prospective

\footnotetext{
* Corresponding author: Agustin Castiella, Gastroenterology Service, Mendaro Hospital, Barrio Mendarozabal s/n, 20850 Mendaro. Spain. Tel: +34-43032800, Fax:+34-43032856, E-mail: agustincastiella@yahoo.es

DOI:10.5812/hepatmon.823

Copyright $\odot 2012$ Kowsar M.P.Co. All rights reserved.
}

- Please cite this paper as:

Castiella A. Iron Overload and HFE Mutations: Are They Relevant in Cryptogenic Cirrhosis? Hepat Mon. 2012;12(2):126-7 DOI: 10.5812/hepatmon.823

Copyright @ 2012 Kowsar M. P. Co. All rights reserved.

study to investigate the probable association of HFE gene mutations in a group of 100 patients with cryptogenic cirrhosis and compared the results with a control group of 50 normal, unrelated healthy individuals. No homozygotes for C282Y and H63D mutations were found, and only $22 \%$ of the patients and $28 \%$ of controls $(P>0.05)$ were heterozygous for the H63D mutation. Most of the cirrhotic patients and controls with this mutation did not have liver iron overload. Few studies have investigated the frequency of HFE gene mutations in patients with chronic liver diseases and cirrhosis. The results from the Jowkar et al. (4) study are similar to those published from Indian and Turkish patients $(5,6)$. More recently, Sikorska et al. (7) studied iron overload and HFE gene mutations in Polish patients with liver cirrhosis (61 patients), and they were compared with a control group of 42 consecutive patients subjected to liver biopsy because of chronic liver disease. They concluded that iron disorders are frequently detected in patients with liver cirrhosis, but without significant association with HFE gene mutations. Another recent study from India (8) tried to find the association of common HFE mutations and primary iron overload in liver cirrhosis. Of the 496 patients (242 cryptogenic cirrhosis) included in the study, only 13 had iron overload and only two were H63D heterozygous. The overall frequency of the H63D allele in patients and controls was not significantly different $(P<0.17)$. 
Jowkar et al. (4), with their interesting study developed in Iran, seem to reinforce the theory that cryptogenic cirrhosis is not associated with iron overload, nor with major HFE mutations. It also appears that there are no geographical differences, since their results are similar to those published in Poland, Europe.

\section{Authors' Contribution}

None declared.

\section{Financial Disclosure}

None declared.

\section{References}

1. Castiella A, Zapata E, de Juan MD, Otazua P, Fernandez J, Zubiaurre L, et al. Significance of H63D homozygosity in a Basque population with hemochromatosis. J Gastroenterol Hepatol. 2010;25(7):1295-8.
2. de Juan D, Reta A, Castiella A, Pozueta J, Prada A, Cuadrado E. HFE gene mutations analysis in Basque hereditary haemochromatosis patients and controls. EurJ Hum Genet. 2001;9(12):961-4.

3. Frazer DM, Anderson GJ, Ramm GA, Subramaniam VN, Powell LW. How much iron is too much? Expert Rev Gastroenterol Hepatol. 2008;2(3):287-90.

4. Jowkar Z, Geramizadeh B, Shariat M. Frequency of two common HFE gene mutations (C282Y and H63D) in a group of Iranian patients with cryptogenic cirrhosis. Hepat Mon. 2011;11(11):887-89.

5. Dhillon BK, Das R, Garewal G, Chawla Y, Dhiman RK, Das A, et al. Frequency of primary iron overload and HFE gene mutations (C282Y, H63D and S65C) in chronic liver disease patients in north India. World J Gastroenterol. 2007;13(21):2956-9.

6. Yonal O, Hatirnaz O, Akyuz F, Ozbek U, Demir K, Kaymakoglu S, et al. HFE gene mutation, chronic liver disease, and iron overload In Turkey. Dig Dis Sci. 2007;52(11):3298-302.

7. Sikorska K, Romanowski T, Stalke P, Izycka-Swieszewska E, Bielawski KP. Iron overload and HFE gene mutations in Polish patients with liver cirrhosis. Hepatobiliary Pancreat Dis Int. 2011;10(3):270-5.

8. Jain S, Agarwal S, Tamhankar P, Verma P, Choudhuri G. Lack of association of primary iron overload and common HFE gene mutations with liver cirrhosis in adult Indian population. Indian J Gastroenterol. 2011;30(4):161-5. 